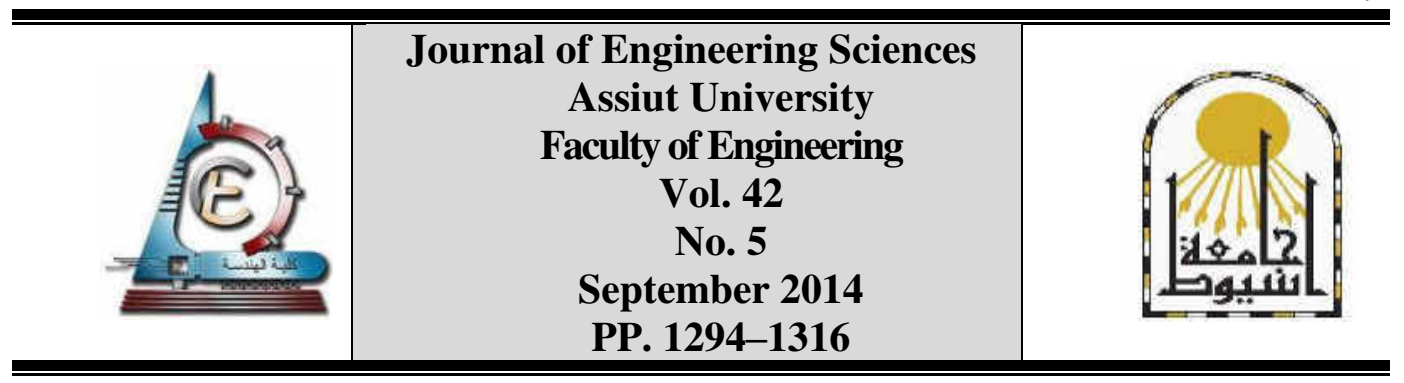

\title{
MUSEUMS BETWEEN TRADITION AND MODERNISM: MEMORIAL MUSEUMS LIKE JEWISH MUSEUM IN BERLIN AS A CASE STUDY
}

\author{
Khaled Abdul-Aziz Osman ${ }^{1}$, Baher Ismail Farahat ${ }^{2}$ \\ ${ }^{1,2}$ MIU University, Egypt.
}

(Received 11 August 2014; Accepted 4 October 2014)

\begin{abstract}
The main objectives of this paper are: To discover new facts related to the museums evolution throughout history till now, to verify the impact of technology on the museums, to analyze the process through which the evolution of museums took place, and to identify the relationship between the main definition of a museum and the emerged museum buildings, in order to achieve the paper main objectives, data presented traces the history of museums, first by noting the etymology of the word museum and its derivatives, next by describing the private collecting conducted in ancient and medieval times, reviewing the development of modern public museums from the Renaissance to the present day, and finally keeping shedding the light on the role of technology on the modern development and transformation of museums, the functionalities of the traditional typologies and the evolution of new ones, the paper hypothesis to be tested is: The historical target of museums had been subjected to many modifications due to the technological, political and social modifications that have altered the general mission of the museum as the house of collections, the conclusion of the paper would be showing whether the actual mission of museums today is still taken into consideration within the new typologies as well as deriving the attained result after all the presented information to derive a general result proving the hypothesis stated, architecture is a clear reflection of the society, so it is subjected to dramatic changes, therefore it is not appropriate to design today in the manners, ideas, and believes of yesterday.
\end{abstract}

Keywords: Mouseion and Museum, Form and Morphology, Memorial Museums

\section{Introduction}

\subsection{General background}

"A hospital is a hospital, A library is a library, A rose is a rose, But a museum is colonial Williamsburg, Mrs. Wilkerson's Figure Bottle Museum, The Museum of Modern Art, The Sea Lion Caves, The American Museum of National History, The Barton Museum of Whiskey History, The Cloisters, and Noelle's Ark and Chimpanzee Farm and Gorilla Show" [6], Museums existed ever since the classical eras as temples dedicated for the goddesses, it

* Corresponding author

E- mail address: khaledkham@hotmail.com 
is witnessed some evolution until transforming from a private collection space into the public museum, ever since the industrial revolution technology had stricken nearly all fields leaving a drastic change in some, modifying, improving and sometimes deteriorating others.

It had created another social modification into all societies as well, concerning the architectural fields, technology had certainly made a vital impact, new technologies generated new design and construction methods, then, technology had been able to strike the various building typologies modifying not only their forms and construction methods, but also their functionalities, and meanings, the museum relationship to its collections has already changed, the distinct edges of differing functioning among libraries, memorials, social services were the major inducer of the museum main mission deformation, therefore it is noticed that the traditional role of the museum has changed.

\subsection{Paper objectives, hypothesis and methodology}

The Objectives of this paper are: To discover new facts related to the museums evolution throughout history till now, to verify the impact of technology on the museums, to analyze the process through which the evolution of museums took place, and to identify the relationship between the main definition of a museum and the emerged museum buildings.

The paper hypothesis to be tested is: The historical target of museums had been subjected to many modifications due to the technological, political and social modifications that have altered the general mission of the museum as the house of collections, and the role of the museum is to increase the awareness of the society.

The paper methodology is a qualitative method as the paper aims to investigate the reasons and target of the proposed topic, the data collection is based on the criteria of multiple theoretical references related to the history of museum buildings and tracking down the influential factors that led to the new typologies, in addition, the paper involves the analysis of several typologies in general and memorial museums in specific, with the analysis of one selected example serving the assigned target.

\section{From mouseion to museum}

\subsection{The definition of a Museum and the emerged museum buildings}

The word museum has classical origins, in its Greek form, mouseion, it meant "seat of the Muses", these muses are each possessing a different ability and source of inspiration; designated as a philosophical institution, for example, the Musaeum or Mouseion at Alexandria, which included the famous Library of Alexandria, was an institution founded by Ptolemy I or, perhaps, by Ptolemy II, This original Musaeum "Institution of the Muses" was the home of music or poetry, this original Musaeum was the source for the modern usage of the word museum [9].

The use of the Latin derivation, museum, appears to have been restricted in Roman times mainly to places of philosophical discussion, the word museum was revived in 15 thcentury Europe to describe the collection of Lorenzo de' Medici in Florence, but the term conveyed the concept of comprehensiveness rather than denoting a building, by the 17th century museum was being used in Europe to describe collections of curiosities, nevertheless the idea of an institution called a museum and established to preserve and display a collection to the public was well established in the 18th century, indeed, Denis Diderot outlined a detailed scheme for a national museum for France in the ninth volume of his Encyclopedia, published in 1765 [11]. 


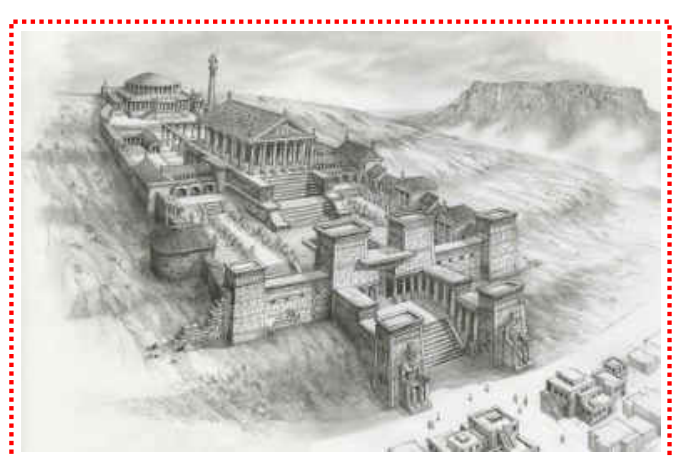

Fig. 1. The Ancient Library of Alexandria, Mouseion at Alexandria.

Source:http://www.crystalinks.com/libraryof alexandria.html

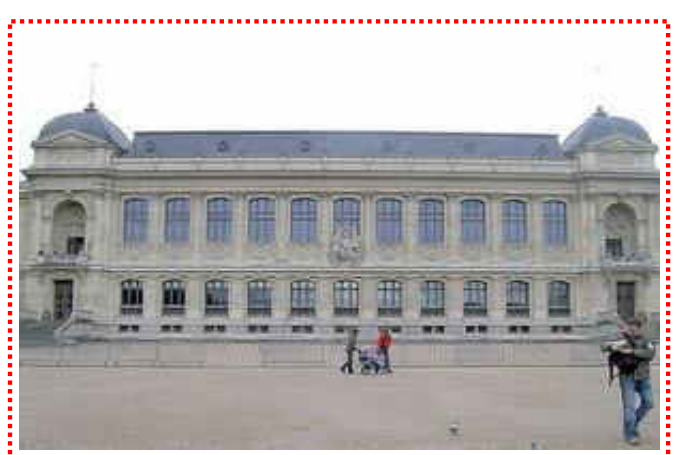

Fig. 2. National Museum of Natural History in Paris, France.

Source: http://bestmuseums.com/france/102national-museum-of-natural-history-in-paris

Use of the word museum during the 19th and most of the 20th century denoted a building housing cultural material to which the public had access, later, as museums continued to respond to the societies that created them, the emphasis on the building itself became less dominant, open-air museums, comprising a series of buildings preserved as objects, and eco museums, involving the interpretation of all aspects of an outdoor environment [11].

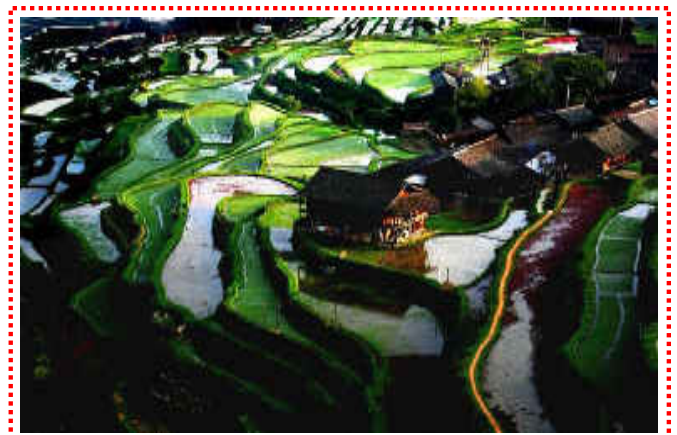

Fig. 3. Tangan Dong Ethnic Eco-Museum, China.

Source:http://www.absolutechinatours.com/ Liping-County-attractions/tangan-dong

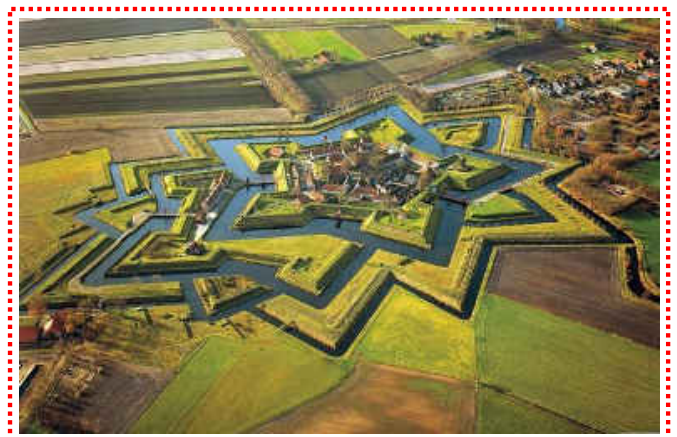

Fig. 4. Open Air Museum, Fort Bourtange, Netherlands.

Source:http://www.travelingtotally.com/bestdestinations/open-air-museum-fort-bourtange

\subsection{The historical evolution of museums}

The precursors of Museums is the origins of the twin concepts of preservation and interpretation, which form the basis of the museum, lie in the human propensity to acquire and inquire, collections of objects have been found through ages as long as civilizations had existed each for a unique purpose, a brief illustration of the several eras before the actual rise of muses shows collections of objects in Paleolithic burials, a development toward the idea of the museum certainly occurred early in the 2nd millennium BC in Mesopotamia, where copies of old inscriptions were used in the schools [11].

The first evidence closest to the concept of a museum dates back to the ancient Greek myths, Museums were defined as "Adobes of the muses", the origin of the Greek word "Museion" which means the temple of the goddesses called "Muses", according to these myths, the word "muse" derived from the word "men" meaning wisdom, thought and creativity means muse; source of inspiration, these muses referred to skills and inspirations ranging from music 
to dance, theatre and history but there were no muses in plastic arts, paintings, sculpture, and ceramic, so, the collection of objects with artistic values was first undertaken by the Greeks [3].

Yet, the first development that can be cited as the nucleus for the museum concept is the Great Museum of Alexandria, the Museum of Alexandria, established in 4th century BC, was the first museum that presented collection, exhibition, preservation and classification missions or museums in historical development, it is considered as the temple of the thought to bring together all cultural indicators of the world in the same location [1].

\subsection{The museum}

The following centuries after the middle ages in the period of Renaissance had witnessed some social changes where the rational muses of the Greek had been recaptured leading eventually to a major evolution of the museum as a separate building type dedicated to the public, these changes were on basis of social interests such as the veneration of the past and of its personalities in Asia which led to the collection of objects, as well as the developing interest in human as well as natural history in the 16th century led to the creation of specialized collections, at about the same time, Islamic communities were making collections of relics at the tombs of early Muslim martyrs, the idea of Waqf, whereby property was given for the public good and for religious purposes, also resulted in the formation of collections, in tropical Africa, the collection of objects also has a long history, as instanced in wayside shrines and certain religious ceremonies [1].

Hence, it is noticed that museum evolution can trace some of its origins to private collections maintained by prominent individuals, these Renaissance collections were symbols of social prestige and served as an important element in the traditions of the nobility, but over time a developing spirit of inquiry brought to collecting a different meaning and purpose as well as a much wider group of practitioners, these new collectors had no such guarantee of succession, if this guarantee could not be found in the family unit, then the route of succession had to be found elsewhere, and the corporate unit provided greater security, furthermore, if knowledge were to have lasting significance, it had to be transmitted in the public domain, it is the transfer of collections from the private to the public domain that has launched creation of the public Museum buildings [11].

Institutionalization of museums started in the "Ashmolean Museum (1683)" located in Oxford University in England as the first museum space open to the public, it was made on the condition that a place should be built to receive it, the 18th century saw the flowering of the enlightenment and the encyclopedic spirit, as well as a growing taste for the exotic, these influences, encouraged by increasing world exploration, and by developing industrialization, were evident in the opening of two of Europe's outstanding museums, the British Museum, in London (1759), and the Louvre, in Paris (1793), the British Museum was formed as the result of the government's acceptance of responsibility to preserve and maintain collections not only for the inspection and entertainment, but also for the general use and benefit of the public; the leading museum in the transformation from the culture of collections to the memory rooms of the enlightenment period is the Louvre museum, the museum created by housing all the collections of the royalty in Louvre Palace after the 1789 revolution has destroyed the structure that attributed art works only to royalty and made them property of the public, it hosts the Grande Gallery which was opened to the public in 1793 [11]. 

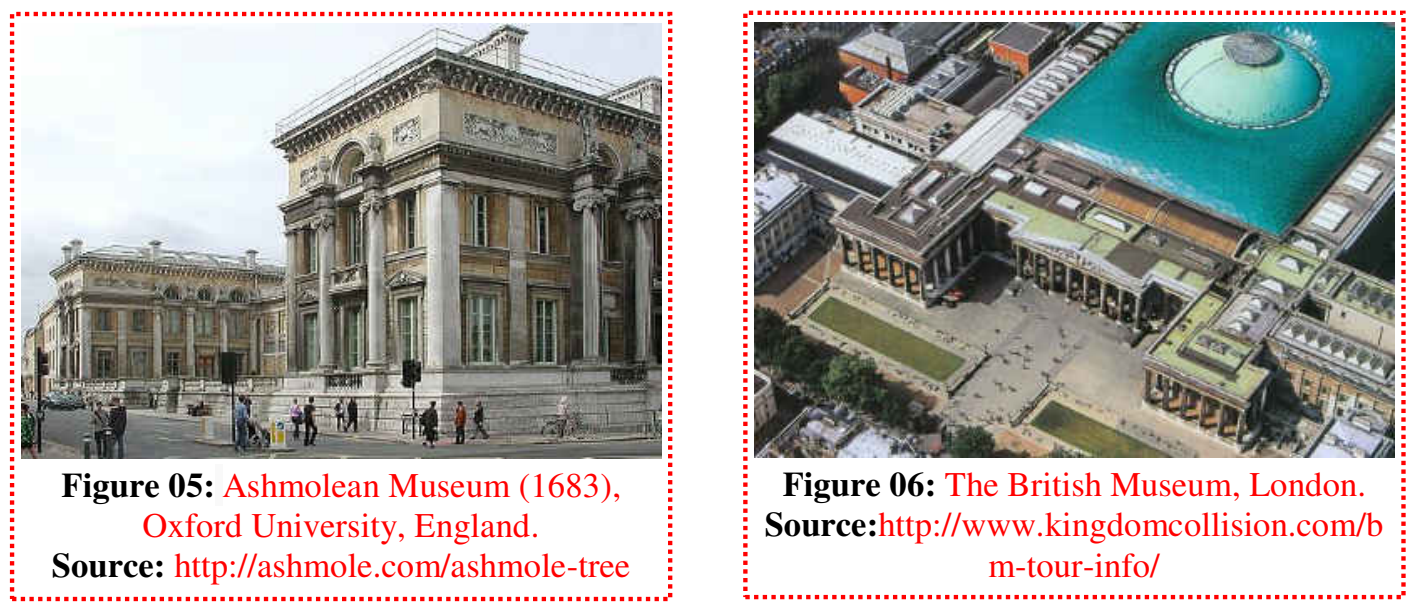

\section{The development of modern museums}

\subsection{The Museum typologies}

\subsubsection{The museum and technological advance}

Since the invention of the modern museum, from the end of the 18th century and the beginning of the 19th, while old heritage buildings were also being reconverted for museum use, a specific architecture evolved that was linked to the requirements of preserving, researching and communicating collections through permanent or temporary exhibitions, this architecture is evident in the earliest museum buildings as much as in the most contemporary ones, the architectural vocabulary has itself influenced the development of the idea of the museum, thus the form of the temple with a cupola and columned portico became established along with the gallery, conceived as one of the main models for fine arts museums, and by extension gave rise to the names gallery, gallery and, galleria in France, Italy and Germany and in Anglo-American countries [5].

The invention of electricity greatly facilitated these improvements and allowed the lighting systems to be completely revised new functions that emerged in the second half of the 20th century led to major changes [5]:

- The increase in the number of temporary exhibitions led to a different distribution of collections between the permanent exhibition and storage spaces; the development of visitor facilities, the educational workshops and rest areas, the creation of large multi-purpose spaces; the development of bookshops, restaurants and shops for selling items relating to the exhibitions.

- The decentralization by regrouping and by subcontracting some museum operations required the building or installation of specialized autonomous buildings: firstly, restoration workshops and laboratories which could specialize while serving several museums, then storage areas located away from the exhibition spaces, the changes taking place to the functionalities of the museum did not just add new spaces to the traditional function of the museum but also affected the traditional exhibitions and galleries and exhibiting methods.

- The development of new technologies and computer-aided design has popularized the creation of museums on the internet with exhibitions that can only be visited on screen or via digital media, they open up possibilities such as collecting objects and 
new ways of display that traditional exhibitions of material objects do not always have, furthermore, there are four new important approaches had emerged in today's museum concepts: virtual museum, touchable museum, mobile museum and foundation museum.

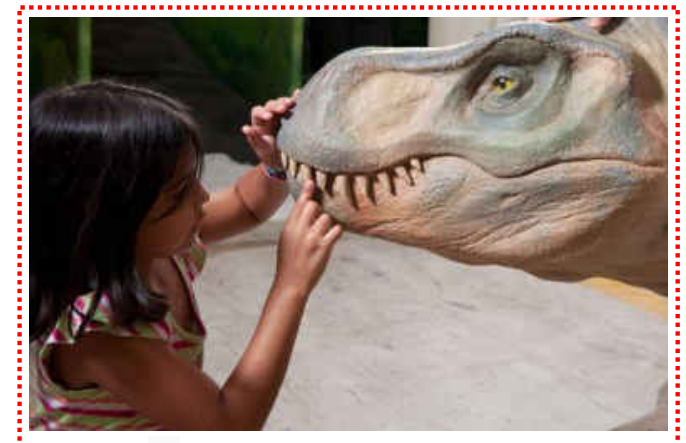

Fig. 7. Touchable museum at Glazer Children's Museum, Alaska.

Source:http://tbo.com/events/touch-

dinosaurs-dig-for-fossils-at-tampas-glazer

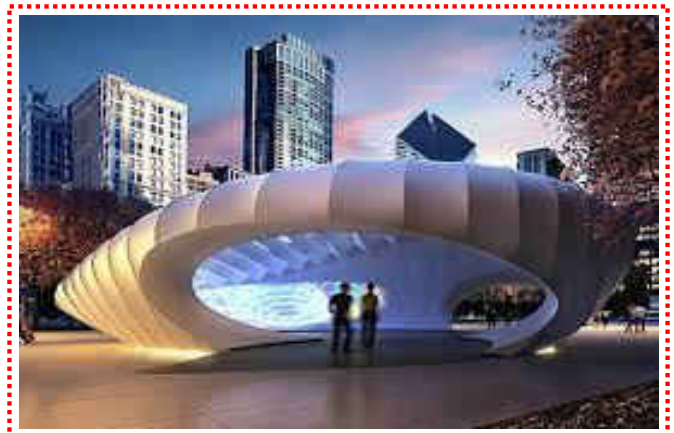

Fig. 8. Mobile Museum in Chicago's Millennium Park, Zaha Hadid.

Source:http://www.dvice.com/archives/2009/ 05/zaha_hadid_unve.php

- The idea of exhibits considerably changed during years rather than awesome display of exhibits with "do not touch" restriction, the display has forms of inactive, active and interactive types, this concept (active / interactive) encourages public participation through visual demonstration, films and lectures are more encouraging and entertaining.

Influence of industry and science, in Britain, The support of museums by local authorities was seen as a means of providing both instruction and entertainment to the increasingly urbanized population and became the subject of special legislation in 1845 , Museums were also viewed as a vehicle for promoting industrial design and scientific/technical achievement, such promotion was the motivation behind the precursor of the Victoria and Albert Museum (for decorative arts) and the Science Museum, international exhibitions have contributed significantly to the formation of a number of museums since then, including the Technical Museum of Industry and Trade in Vienna and the Palace of Discovery in Paris [11].

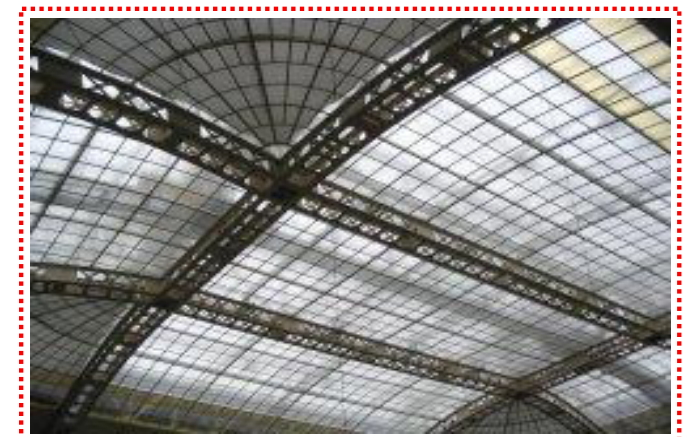

Fig. 9. Influence of industry, Technical Museum of Industry and Trade in Vienna.

Source:http://www.visitingvienna.com/sights /museums/technicalmuseum

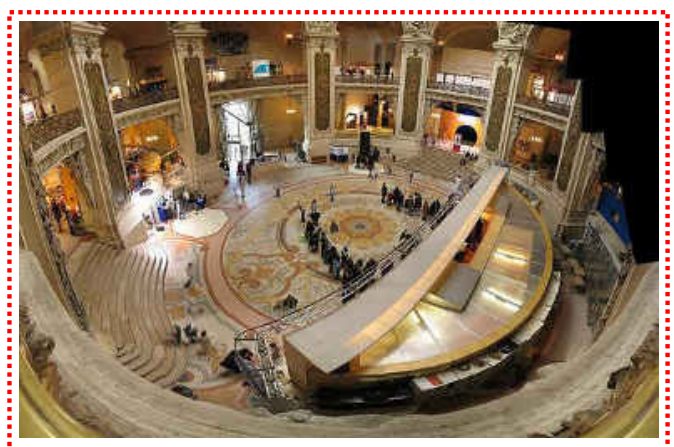

Fig. 10. The Palace of Discovery, the Space Odyssey of Ariane V, Paris.

Source: http://www.worldtoptop.com/palaisde-la-decouverte 
The middle of the 19th century saw the establishment of a number of other well-known museums, in Canada the collection of the National Museum commenced in 1843 in Montreal as part of the Geological Survey, the Ontario Provincial Museum, was founded in 1855, in Australia the National Museum of Victoria was established at Melbourne in 1854; it was followed by the National Gallery of Victoria in 1861 and the Science Museum of Victoria in 1870, in Cairo the Egyptian Museum was established in 1858, these all followed the European model, and even in South America art collections tended to be predominately of European origin [11].
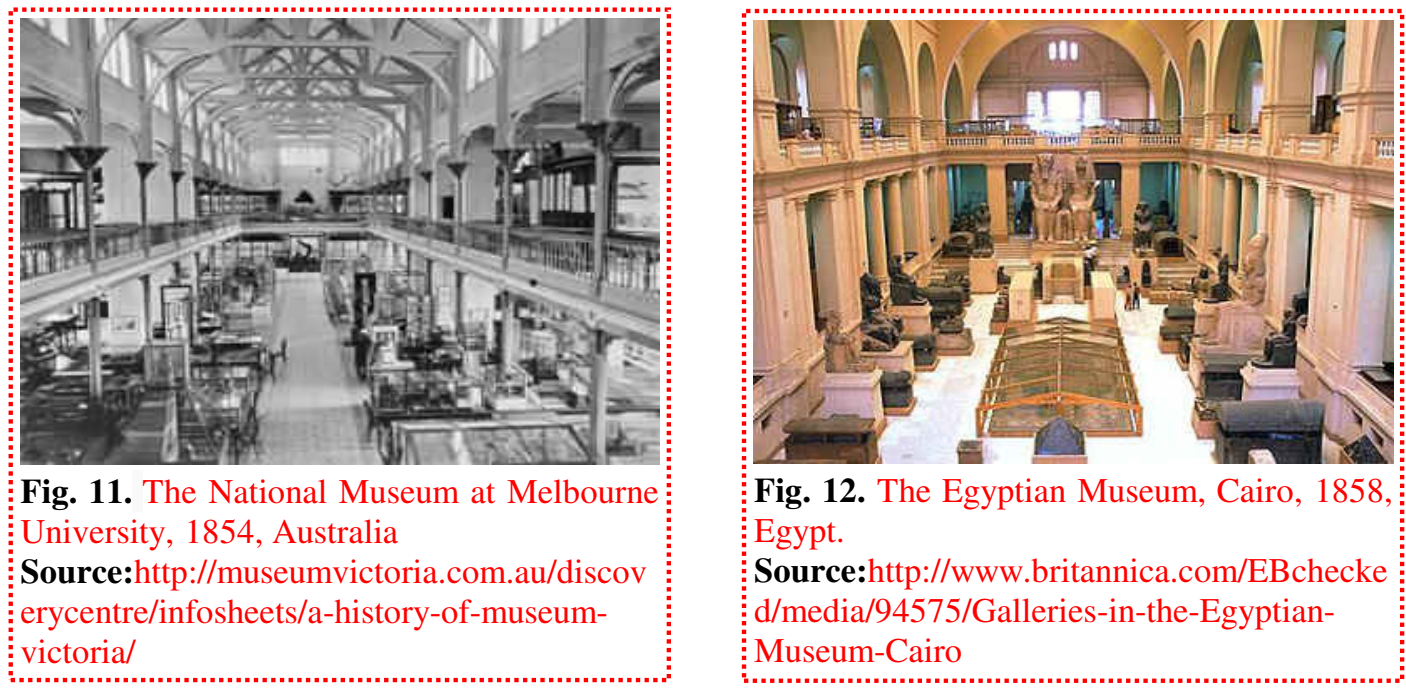

Fig. 12. The Egyptian Museum, Cairo, 1858, Egypt.

Source:http://www.britannica.com/EBchecke d/media/94575/Galleries-in-the-EgyptianMuseum-Cairo

The project of the millennium, as it has been described, The Grand Egyptian Museum (GEM) is designed to include the latest technology, including virtual reality, the museum will also be an international center of communication between museums, to promote direct contact with other local and international museums, The Grand Egyptian Museum will include a children's museum, conference center, training center, and workshops similar to the old Pharaonic places [13].

It will also house a fully-computerized information centre for Egyptologists and a training centre where short courses on Egyptology will be given to museum curators and conservators, specialized courses for IT specialists will also be held, a special section for children will be created in order to help youngsters learn about their heritage, the mission of the museum is to preserve, document, conserve, research and exhibit collections, as well as to educate and entertain visitors [12].

The facade will be constructed of translucent alabaster, allowing the day-light to penetrate inside the museum's halls.

The winning Henegan Ping design team looked to monuments and archaeological sites throughout Egypt for inspiration, computer animated simulations (illustrating scenes like Carter's first glimpse of Tutankhamen's tomb), a children's learning centre and specialneeds access make the museum sound futuristic compared to the century-old Egyptian Museum in Midan Tahrir [12]. 


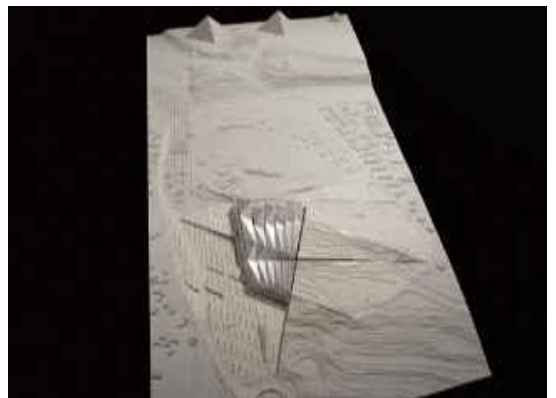

Fig. 13. Grand Egyptian Museum (GEM), Near Giza Plateau, Egypt.

Source:http://www.hparc.com/work/thegrand-egyptian-museum/

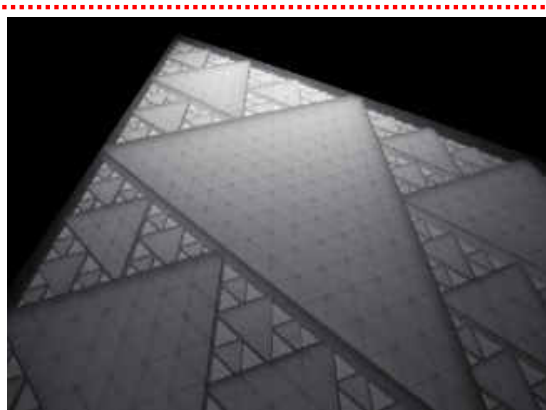

Fig. 14. GEM, The facade will be constructed of translucent alabaster.

Source:http://www.hparc.com/work/thegrand-egyptian-museum/

To demonstrate the change within the museums mission, the (figure 01) shows the typologies of museums and their content based upon various missions to which museums are dedicated, at one end the object display (a presentation of objects purely for the object's sake; no interpretive information is involved), at the other extreme is the information display (indents to communicate an idea or ideas that the exhibitor has determined $60 \%$ information and $40 \%$ objects) [2].

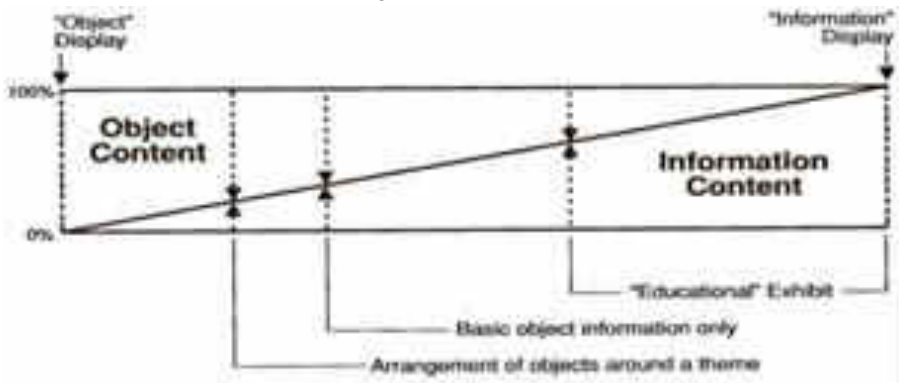

Fig. 15. Exhibition Content Scale.

Source: Dean, D. (1996), "Museum Exhibition: Theory and Practice", Routledge, New York.

\subsubsection{The impact of the World War II}

The years immediately following World War II were a period of remarkable achievement for museums, this was reflected both in international and national policy and in the individual museums as they responded to a rapidly changing, better-educated society, Museums became an educational facility, a source of leisure activity, and a medium of communication, their strength lay in the fact that they were repositories of the "real thing," which - unlike the surrounding world of plastics, reproduced images, and a deteriorating natural and human environment could inspire and invoke a sense of wonder, reality, stability, and even nostalgia [11].

Among other factors that have contributed to the development of museums since the mid20th century is an increased awareness of the environment and the need to preserve it, many sites of scientific significance have been preserved and interpreted, sometimes under the aegis of a national park service, and historic sites and buildings have been restored, the latter sometimes being used as museums, this has led to the development of historic and natural landscapes as museums became members of a team comprising scientists as conservators, 
designers to assist in exhibition work, educators to develop facilities for both students and the public, information scientists to handle the scientific data inherent in collections [7].

\subsubsection{The museum, a social service as an extension of needs}

Other of museum typologies had emerged due to the social needs moving towards the information content display rather than the exhibition of object content status of traditional museums, social museums and community museums have been developed in recent decades in order to emphasize the specific connection that these museums wish to build with their public, these museums, traditionally ethnographic museums, present themselves as establishments which have strong ties with their public, who is at the centre of their work, although the nature of their respective objectives is similar, their management style differs, as does their relation with the public [2].

Social reforms to overcome problems resulting from industrialization contributed to the development of municipal Museums, the support of museums by local authorities was seen as a means of providing both instruction and entertainment, Museums were also viewed as a vehicle for promoting industrial design and scientific achievement, Increasing interest in antiquities led to the excavation of local archaeological sites and had an impact on development of history museums; the term history museum is often used for a wide variety of museums where collections are amassed and presented to give a chronological perspective, history museums may include cultural form, specialized form of the history museum collects and exhibits material from an ethnographic viewpoint, there is nevertheless a distinctive type that specializes in it: the antique museum and archaeology museum which is concerned mainly with historical evidence recovered from the ground and in many cases provides information on a period for which the written record can make little or no contribution [11].

\subsection{The museum form and morphology}

The evolution and modifications that occurred with respect to the museums had not been restricted to the museum functions, the implications of the industrial and technological revolution had effected the construction, structural and architectural features of the museum building itself, In 1891 Gottfried Semper completed the Kunsthistorisches Museum in Vienna as a palace of culture, designed according to the Renaissance model of interconnecting spaces, this palace-museum merged culture and power to convey an image of an idyllic past, they achieved a perfect unity between the works accommodated and architecture [10].

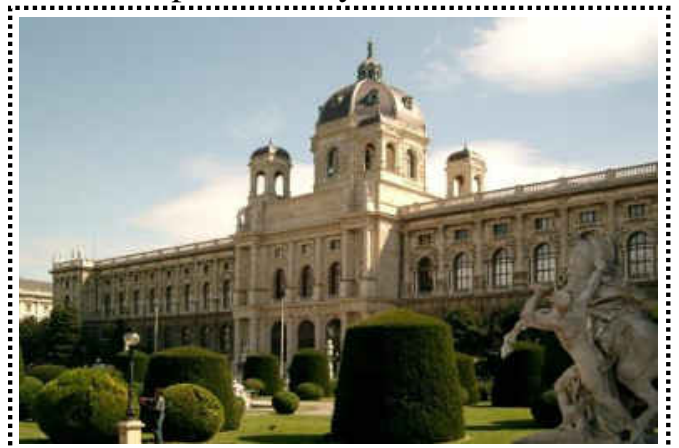

Fig. 16. Kunsthistorisches Museum, Vienna, Gottfried Semper (Exterior View).

Source:http://xaxor.com/travel/12224kunsthistorisches-museum-vienna-austria

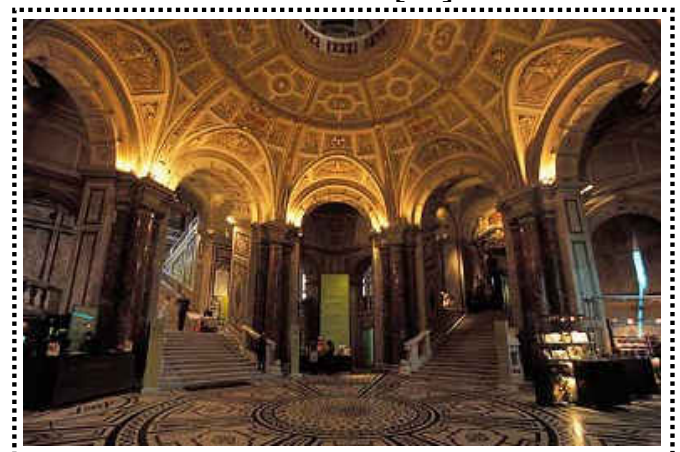

Fig. 17. Kunsthistorisches Museum, Vienna, Gottfried Semper (Interior View).

Source:http://xaxor.com/travel/12224kunsthistorisches-museum-vienna-austria 
In an attempt to avoid the imitations of 19th-century architects, the Modernists reinterpreted the act of remembering, in addition to the utopianism and abstraction in their work, they sought to reclaim influences from the past rather than its direct representation, for the 20th-century architect, history was a source of inspiration, archaeology laid the foundation for modern design and fashioned it from the inside out.

It was not until 1959, however, that a new vision for the museum and its use of space appeared, this is the year that Frank Lloyd Wright's Guggenheim Museum in New York City was completed, based on the principle of an ascending helix, as if aspiring for verticality and growth, the building breaks with conventional geometry, with the Guggenheim, Wright formulated a different approach to museum design, one in which the spatial setting has an effect on the exhibitions and changes the viewer's perception of the works on display, the space of the museum now had a meaning of its own, today this internal contradiction between the content and the container has become the rule, with the Guggenheim, memory, or the act of remembering, resides at the intersection of resources and materials [10].

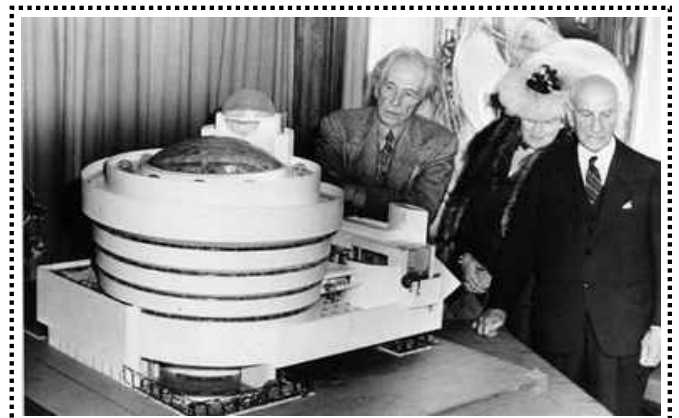

Fig. 18. Guggenheim Museum, New York, Frank Lloyd Wright (Model View).

Source: http://www.archicentral.com/franklloyd-wright-from-within-outward-15181

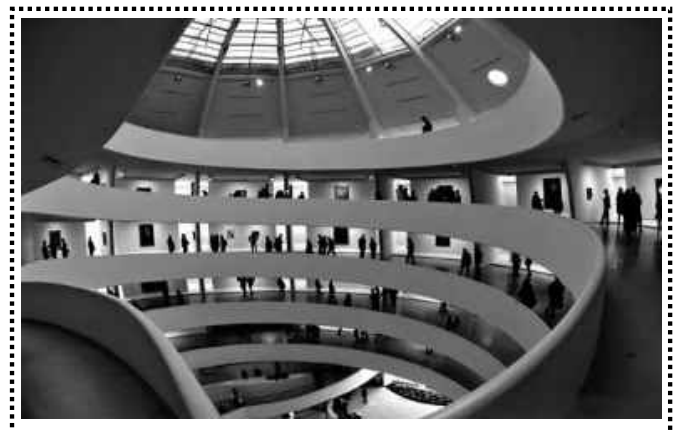

Fig. 19. Guggenheim Museum, New York, Frank Lloyd Wright (Interior View).

Source: http://www.archicentral.com/franklloyd-wright-from-within-outward-15181

In the 1960s, new trends in architecture led to the development of the museum as a kind of kinetic, the introduction of a movable skeletal structure allowed flexibility of use, as in Renzo Piano and Richard Rogers' design for the Pompidou Centre in Paris, the Beaubourg, as the museum is often referred to, is an example of an engineer's utopia, the external escalators and flexible space create a museum architecture liberated from its contents, as a container, the museum embraces the contradictions of modernity and is an eloquent and abstract structure, independent of its artistic contents [10].

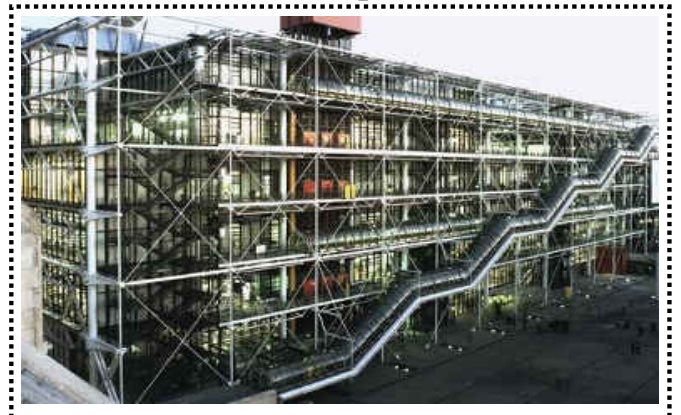

Fig. 20. Centre Pompidou, Paris, Renzo Piano and Richard Rogers (Exterior View).

Source:http://www.etudiantdeparis.fr/ressour ces/centre-pompidou-musee-national

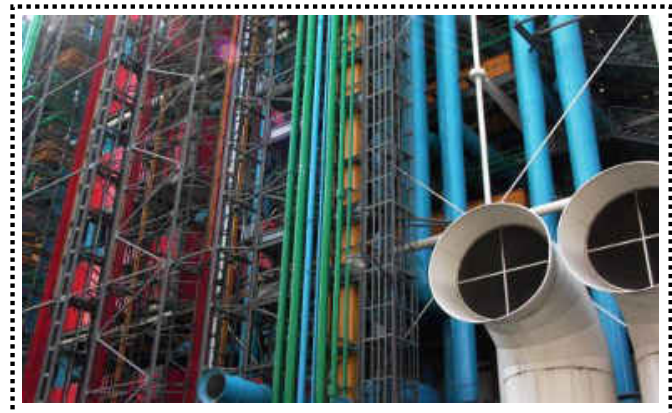

Fig. 21. Centre Pompidou, Paris, Renzo Piano and Richard Rogers (Detail View).

Source:http://www.etudiantdeparis.fr/ressour ces/centre-pompidou-musee-national 
In the post-modern climate of the $80 \mathrm{~s}$, we see a transition from the city-museum to the museum-city, where the museum itself becomes a kind of a citadel, a complex image of solids and voids, with components of public space included within it, a vision of the museum developed as a reverse image of the city, James Stirling's 1984 design for the Neue Staatsgalerie in Stuttgart is one of the best examples of the principle of museum-as-urban-system, it is an articulated container that, by means of its central courtyard, directs circulation through a multilayered scheme, between inside and outside and between history and the city [10].

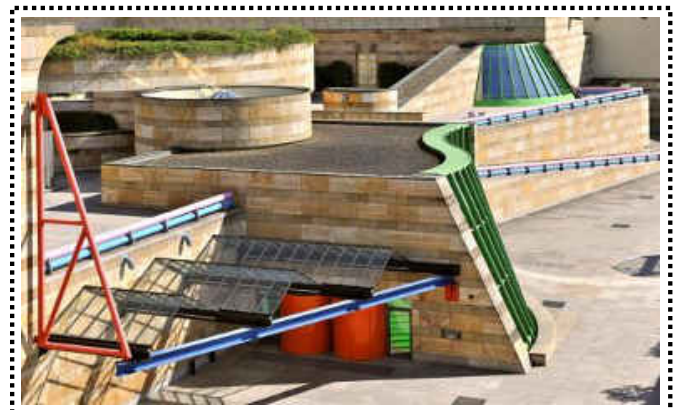

Fig. 22. Neue Staatsgalerie, Stuttgart, 1984, James Stirling (Exterior View).

Source: http://www.architectural-review.com /essays/typology-quarterly-museums

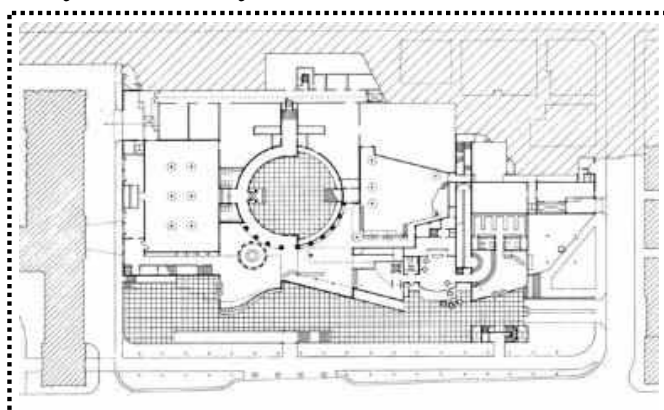

Fig. 23. Neue Staatsgalerie, Stuttgart, 1984, James Stirling (Plan).

Source: http://www.architectural-review.com /essays/typology-quarterly-museums

With the Wexner Centre for the Arts in Columbus, Ohio, Peter Eisenman recalled the history of the place by bringing the theme of towers to the forefront, by means of the threedimensional structure of the frame inserted between the existing buildings, he broke the symmetrical and self-referential patterns of Postmodernism's nostalgic idioms and paved the way for the idea of deconstruction [10], the Wexner Centre was Eisenman's first public building: it solves an interesting architectural conundrum by following both the grid of the city and the grid of the campus, which do not join up.

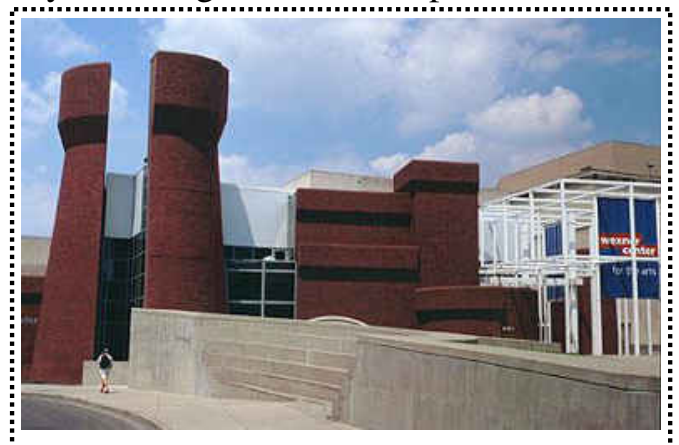

Fig. 24. Wexner Centre for the Arts in Columbus, Ohio, Peter Eisenman (Exterior).

\section{Source:}

http://www.galinsky.com/buildings/wexner

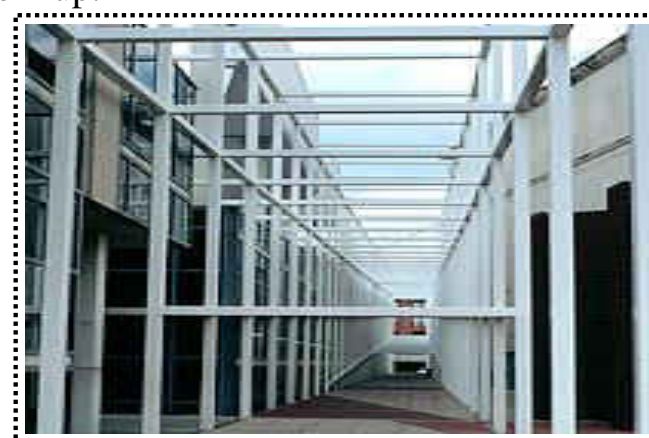

Fig. 25. Wexner Centre for the Arts in Columbus, Ohio, Peter Eisenman (Interior). Source:

http://www.galinsky.com/buildings/wexner

In 1988 at a time when the crisis in the property market was leading intellectuals \& artists to question the meaning of design, the Deconstruction Architecture exhibition was held at the Museum of Modern Art in New York and sparked new concerns about architectural composition, in Gehry's design for the Guggenheim Museum, articulation became spectacular, Like some futuristic work, the museum traces the defining lines of the city like an urban sculpture, and an icon in the landscape of public domain [10]. 


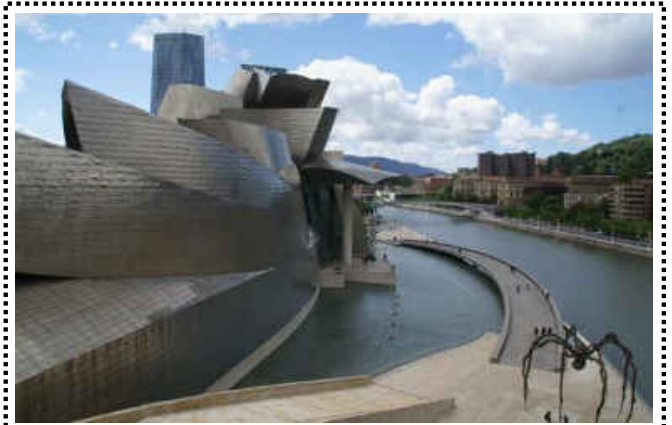

Fig. 26. Guggenheim Museum, Bilbao, 1999, Frank Gehry (Exterior View).

Source:http://www.archdaily.com/422470/ad

-classics-the-guggenheim-museum-bilbao

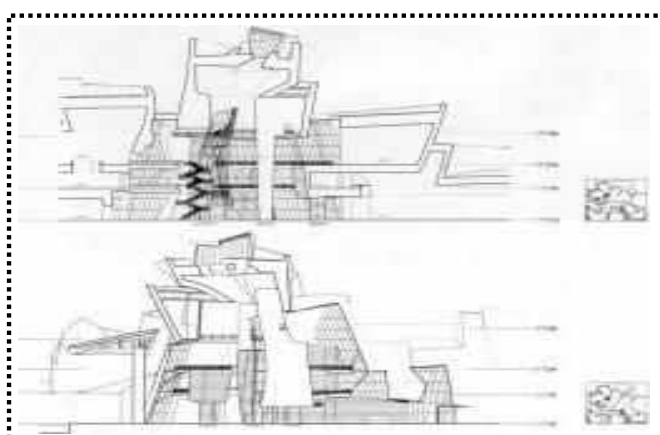

Fig. 27. Guggenheim Museum, Bilbao, 1999, Frank Gehry (Architectural Drawing).

Source:http://www.archdaily.com/422470/ad -classics-the-guggenheim-museum-bilbao

Spatial and other types of relationships now took precedence; the void was more important than the solid; and the dynamics of movement replaced the linearity of 19thcentury plans, the Guggenheim Museum in Bilbao by Frank Gehry, the Jewish Museum in Berlin by Daniel Libeskind and the Kiasma Museum in Helsinki by Steven Holl are the most comprehensive examples of this development, Steven Holl with his Kiasma Museum created a Le Corbusier-style promenade and fashioned the linear and spiral space into a design that speaks of the cultural and social blend of our time [10].

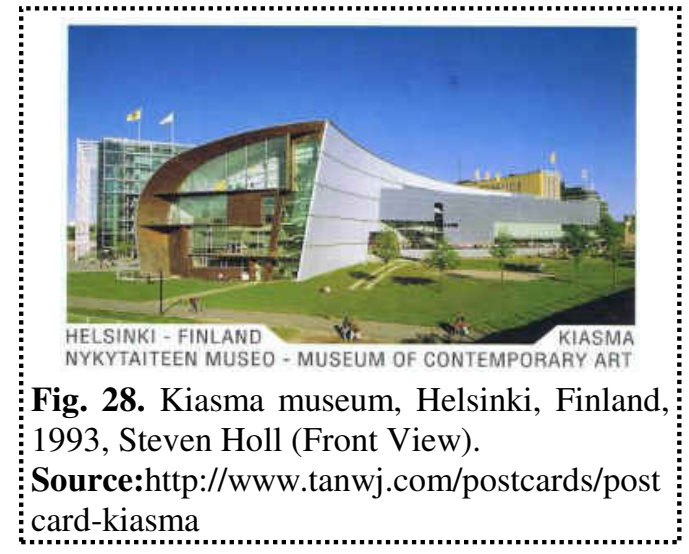

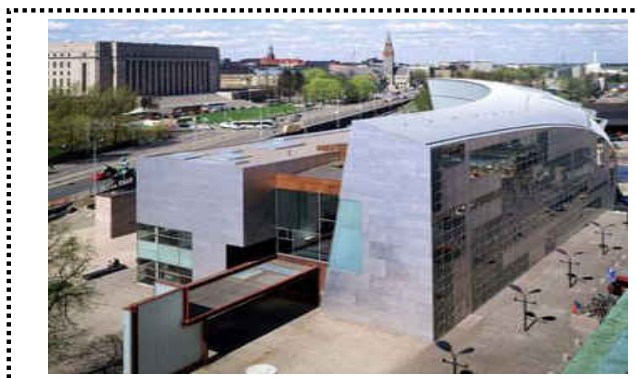

Fig. 29. Kiasma museum, Helsinki, Finland, 1993, Steven Holl (Back View).

Source:http://www.arcspace.com/features/st ven-holl-architects/kiasma-museum

In recent years, because of the change in how the buildings are related once used as industrial establishments, they are now given new life, implanting is the central theme of this new concept design, the idea of implanting was foreshadowed in philosophy, and the museum-organ concept design was superseded by the prosthetic, the museum-organ concept reflects the objective ideals of modernity with its one-to-one relationship between form and function, whiles the prosthetic, as analyzed by post-structuralism philosophy, is derived from the idea of hierarchical space as dictated by static functions [10].

Today, based on abstraction, the relationship between a museum and its context is translated into formal and figural principles, which interpret the landscape as an unveiling project, the idea that connects the museum to landscape originated when environmental protection issues became pressing as a result of land exploitation, technological accidents, pollution of the natural environment by oil tankers and the destruction of the green lungs ${ }^{6}$ of the Amazon, And, even more importantly, it is the Land Art movement that grew up in 
America in the " 60 s and ' 70 s to which we owe a new vision of the landscape, if we look more closely at these developments, we can gain an understanding of certain lines of research that came together in contemporary museum architecture [10].

Overlooking the wild Atlantic, Paulo David's Art Centre at Casa da Mudas becomes a man-made cliff top on the island of Madeira, although many Land Art artists came from Minimalism, Land Art opposed Minimalism's emphasis on serial, geometric monolithic forms. Land artists reclaimed both materials and processes from the land to produce their work. just as the artist left the easel and studio to paint outdoors, so the museum left the confinement of walls and rooms for the natural environment.

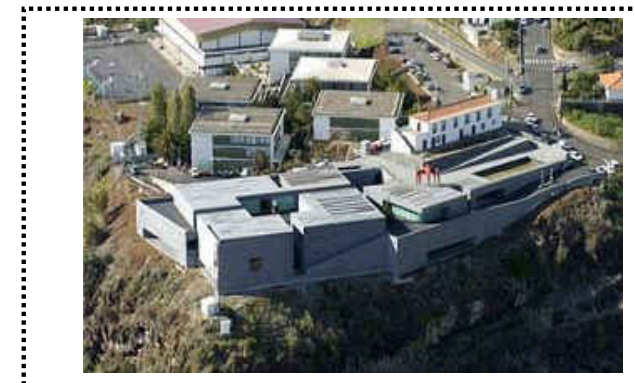

Fig. 30. Paulo David's Art Centre at Casa da Mudas, The Island of Madeira.

Source:http://kuentro.blogspot.com/2011_03 01 archive.html

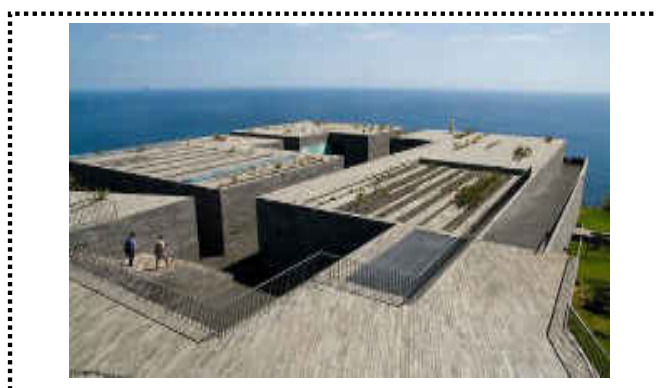

Fig. 31. Paulo David's Art Centre at Casa da Mudas, The Island of Madeira (Entrance).

Source: http://www.bestguide.pt/en/casa-dasmudas

The Grand Egyptian Museum (GEM) project is billed is one of the largest museum developments currently underway globally, with an allocated area of 480,000 square meters, the museum will be located nearly 2 kilometers away from the Giza pyramids adjacent to the Giza plateau, and on completion will become the intersection between modern and ancient Cairo directing the public back to the ancient heritage of Egypt [13].

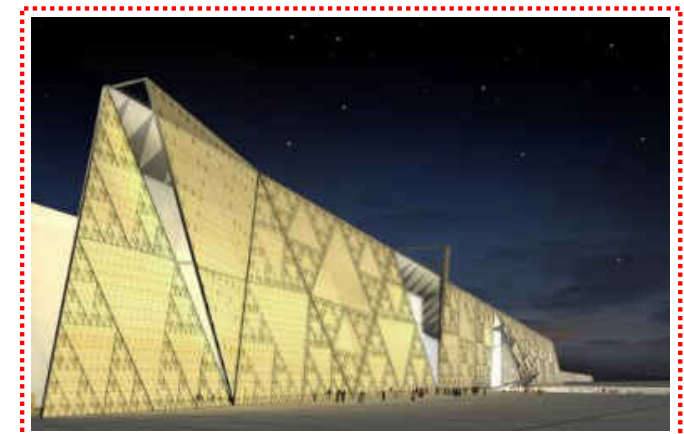

Fig. 32. Grand Egyptian Museum (GEM), Near Giza Plateau, Egypt (Front View).

Source:http://www.hparc.com/work/thegrand-egyptian-museum/

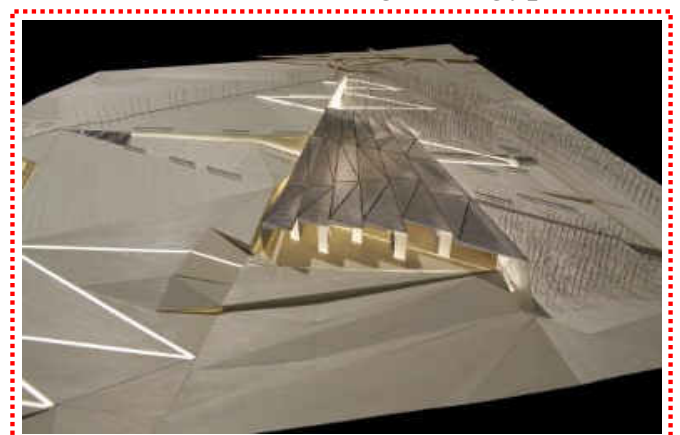

Fig. 33. Grand Egyptian Museum (GEM), Giza Plateau, Egypt (Model View).

Source:http://www.hparc.com/work/thegrand-egyptian-museum/

\section{Typology case study: the case of memorial museums}

The memorial is about moral uncertainty, its political reference points includes the crisis of state modernity, the vulnerability and susceptibility of human rights, and the formation of ethnic diasporas under conditions of tragedy and renewal, Memorial 
Museums is a termed used to identify a specific kind of museums dedicated to a historic event or person commemorating mass suffering of some kind.

\subsection{The traces of memorial museums}

The emergence of this new typology had major historical procedure, this procedure had been induced by two main factors, the political and social modifications that took place, primary it had been notice that across many nations, public commemorations of warfare, political violence, terrorism and discrimination have become a political flashpoint, and the desire of commemoration is traced back to major historical events.

These historical events had been related to the political unrest witnessed worldwide such as the world war and Holocaust memorials provide the essential background for the spread of such museum typologies. these museums are meant to be dedicated to genocide terrorism, political disappearances, nuclear incidents, and other forms of irregular conflict, while Holocaust memorials certainly relate closely to themes of atrocity, repulsiveness, illegality, and degradation that cases share, many holocaust memorials were themselves shaped positively and negatively- in response to the form and meaning of World War memorials.

After the First World War, a common concrete appearance for monuments was established among the nations that fought, nearly every town placed sculptural monuments in a battlefield, civic square park, bridge, parliament building, or church, for instance, and the Tomb of the Unknown Soldier in Arlington Cemetery, Virginia, these monuments varied in splendor, detail, icons imagery, and language according to the nation's prevailing political arrangement and religious and artistic traditions, yet they created a combination of classical and religious themes and motifs of the native landscape which formed the key connection between the cult of the war dead and nationalist self-representation.

This physical and thematic template was re-inscribed after the Second World War where engravings and icons were added for both practical and symbolic reasons. and by then, war memorials became concretized as a sculptural genre, wider cultural significance had been achieved by the first half of the last century, where committees, architects, designers, and landscapers collaborated in constructing the intended aesthetic purposes of the memorials, less explosive, but no less important social developments were also essential to the modern experience of memorials, the rapid growth of urban architecture and the city crowd, the growth of mass media especially visual media such as photography and films, broader access to education, and increased mobility including the nascent development of the mass tourism also form the historical context for today's mode of visiting.

\subsection{The expansion of the memorial museum concept}

\subsubsection{The mission}

A Memorial Museum is a compound made necessary by the complications of conventional museological categories or typologies, a memorial is seen to be, if not apolitical, at least a safe in the refuge of history, in History museums, the prized object has qualities related not primarily to aesthetic excellence, as found in art museums, or the rare and representative specimens that fill natural history museums, but which instead pertain to authenticity.

Memorial Museums, far their apart, are acutely aware if the role of primary artifacts, not only because they give displays a powerful appeal, but also because in many cases the exist as tangible proof in the face of debate about, and even denial of, what transpired, when visiting a 
memorial museum, the theme of historical distance is crucial especially concerning the one not simply reducible to the duration between the time of the event and the present, the museum shall create a relation of intimacy and detachment to an event or person or date based on the affinity and sympathy the visitor anticipate, it is the museums task to contrive the past moments close and pressing to the observing visitor in order to intensify its emotional impact.

\subsubsection{The building and internal spaces}

Without positing that older museums conventions have been eclipsed or abandoned, it is clear that the critical consensus now favors minimalist and abstract design over that which is grandiose and authoritative; de-centered and incommodious space over that which is central and iconic; bodily visitor experiences that are sensory and emotional rather than visual and impassive; interpretive strategies that utilize private, subjective testimony over official historical narratives; salt over stones, perhaps, visitors also hold the basic expectations that the site should remain reliably constant, in order that the memory of the event can be consolidated in a physical form, and to allow the visitation ritual to be repeated over generations.

The attention to visitors' actions is especially important since the memorial itself is not, in a particular sense, the object of the visit, as James Young has recognized, we do not typically go to memorials because it is beautiful, or fascinating - unlike art museums - or because we expect it to reach us a good deal about a subject - unlike standard history exhibit, Instead, he adds, we come in respect bringing with us a sense of history, we reach the memorial with a personal conscience that becomes the reference point that leads us back in time to the persons and events in commemorate, furthermore, Young puts it, "the aim of memorials is not to call attention to their own presence so much as to past events because they are no longer present".

The Memorial Museums are restricted by an emotional and historical weight, the weight of the new mission assigned to the memorial museums obliged the evolution of different display methods which had lead to a major deviation in the typical museology, based on this fact, new activities constituted the trip of the visitor to the memorial museum, these Longstanding activities include: travel to a particular site (perhaps a cemetery, a place that saw death or a town square to where the dead were brought home); attending on a particular date; a physical approach towards the principal monument from a distance, culminating in intimate contact with earth, metal, water, or stone structure; prayer or silent contemplation, as Edward Casey puts it, "honoring in a full-bodied way requires more than a passing praise, it seeks to preserve and stabilize the memory of the honoree, and to do so in a time-binding, invariant manner, the explicit aim is to maintain this memory" [15].

Records and bodies are buried, the weapons, vehicles, uniforms, rations, medals, maps, and propaganda posters that form the collection of the museums are intellectually captivating and often culturally aggrandizing, hence Memorial Museums' collections are often restricted in size, and scope, when materials are recovered, the process often proceeds in an almost archeological fashion, the combination of the catastrophic "story" of the event, its political and existential gravity, and the scarcity of the material traces left behind makes the object that are shown all the more crucial, the Memorial Museum and its event are singularly focused, they have an uncommonly circumscribed mission - that is, to illuminate, commemorate, and educate about a particular, bounded, and vivid historical even - this process does not make the process of exhibiting objects straightforward, yet, a marked feature of the Memorial Museum collection is that it is defined by - or even held hostage to - what the perpetrators in each event produced. 
In addition, new display methods had emerged on its own as a result of the main target of the museum itself, when a story, a case, an event was intended to be recalled, new proof were required, For this reason, the photographic memory of the events and people had been a major part of the museum exhibition, images were considered the representation of both the past and vestigial artifact form since the photographic visualization is capable of inducing the ability of the observer to mentally conceive the quality and scale of the event set for remembrance, as Roland Barthes observed: "In photography I can never deny that the thing has been there", furthermore the Memorial Museum acts as a site of recovery in which the photographs can gain a new value, very few pictures were taken with the expectations that they would one day be shown in a museum; for this reason the few available ones are given great importance in significance of the actual and surviving evidence of the theme addressed, Museums may strike to be as natural home for these kinds of photos, they rely on a radical de-contextualization, not only from the private to the public, but also from the moment that may have been little experienced, to a history that may remain permanent evident [15].

The strategic use of objects, images and spatial effects only goes so far in accounting for the museum's effect on visitors, this illustrates the role of the museums in this case to invariably cherish the public education, the practice of remembrance is largely based on reality effects, these include architectural styles that pointedly show the authenticity of the space through, for instance, exposed wall or glass floors that display archeological finds, stage-set-like scene and rooms and the use of personal testimony where using visual screens or audio devices, a survivor virtually accompanies the visitors as he or she moves through the museum galleries, hence the total physical environment becomes itself the attraction, the Museum objects are spatially arranged and decorated, placed in showcases and lit, and given explanatory panels and audio-visual augmentation before the show opens.

As Maurice Halbwachs wrote that every collective memory unfolds within a spatial framework, now space is a reality that endures: since our impression rush by, we can understand how we capture the past only by understanding how it is, in effect, preserved by our physical surroundings, It is to space - the space we occupy, transverse, have continual access to, or can any time reconstruct in thought and imagination - that we must turn our attention [15].

There are expectations that the memorial buildings should be unique, memorable, and iconic, with some metaphorical visual tie to the event, this shows the importance of the location of the memorial as it requires a live sensory experience, in addition, a richer appreciation of the physical dimension is vital in this experience produced, the memorial space is fundamentally about the representation and symbolization of the events, this is appreciated in the example, later analyzed in the next part, where the case of Daniel Libeskind's uses the architectural "voids "in the Jewish Museum, these voids represent the tragic failure of the enlightenment project, simultaneously with the memory of its human victims, this supports the idea that the museum affective power lies not just in ideas, but also in the experience of the awkward, foreign and claustrophobic spaces [8].

\section{Museums between tradition and modernism: memorial museums like Jewish museum in Berlin as a case study}

Based on the illustration of the memorial museums in the previous part, the selected example Daniel Libeskind's Jewish Museum in Berlin, would be analyzed with respect to the mentioned information, the aim of this analysis is to illustrate an actual example and the way the architect was capable of recalling the memory of the event through several architectural features. 
As Daniel Libeskind, (1998), said that, the official name of the project is 'Jewish Museum' but I have named it 'Between the Lines' because for me it is about two lines of thinking, organization and relationship, one is a straight line, but broken into many fragments, the other is a tortuous line, but continuing indefinitely, the structure of this building goes far beyond the physical realm, it addresses the social structure of Berlin and the absence of Jews in Berlin, Libeskind creates a dialogue between the past and the present of the Holocaust, and most importantly, Libeskind poses the question, how do we deal with the scars from the past [14].

\subsection{The mission}

The Jewish Museum works by provoking an emotional and psychological disturbance in the visitor, a shattering of the ego mirrored in the formal fragmentation of the building, and reconstructing individual subjectivity through the tragic experience of the building, the museum is able to function as a memorial without conventional monumentality.

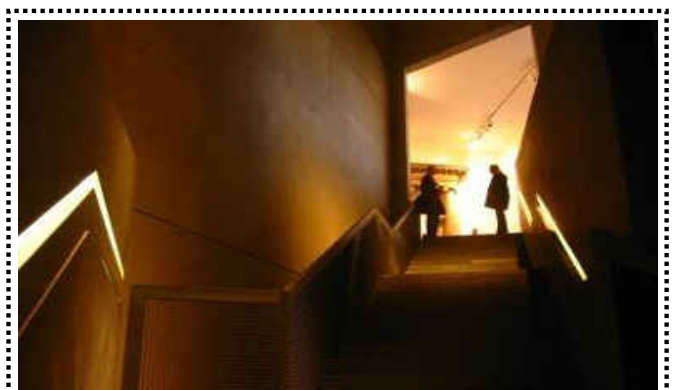

Fig. 34. Museum, provoking an emotional disturbance in the visitor.

Source:http://arq-contemporanea-

agcbb.blogspot.com

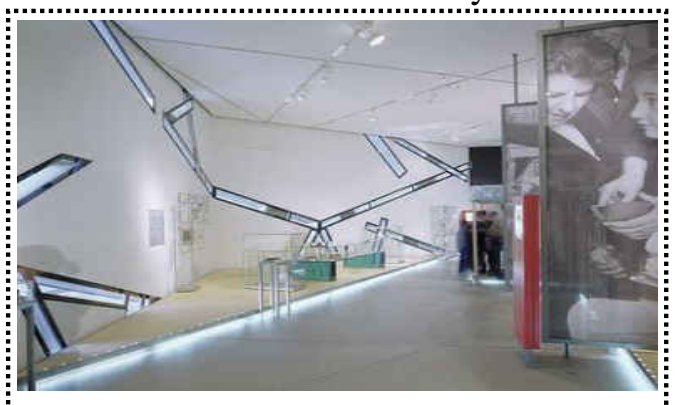

Fig. 35. Museum, Function as a memorial without conventional monumentality.

Source:http://arq-contemporaneaagcbb.blogspot.com

\subsection{The building}

The building form is based on an irrational matrix which resembled a distorted star, an imaginary straight line runs through the entire length of the interior is called Axis of the Void, Libeskind said that, "this line, signifying emptiness, even intersects the exhibition floors with their objects, pictures, and visitors, it stands for radical annihilation", this imaginary line is part of the building, this line symbolizes the destruction of the Jewish population, as it also symbolizes the continuity and connection of this history, the voids, on the other hand, evoke a death that can never be exhibited because Jewish Berlin history has been reduced to ashes [4].

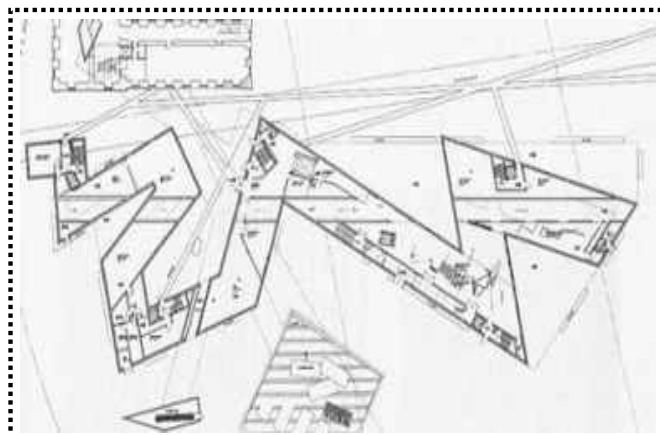

Fig. 36. The Jewish Museum Floor Plan showing the Imaginary line.

Source:http://arq-contemporaneaagcbb.blogspot.com

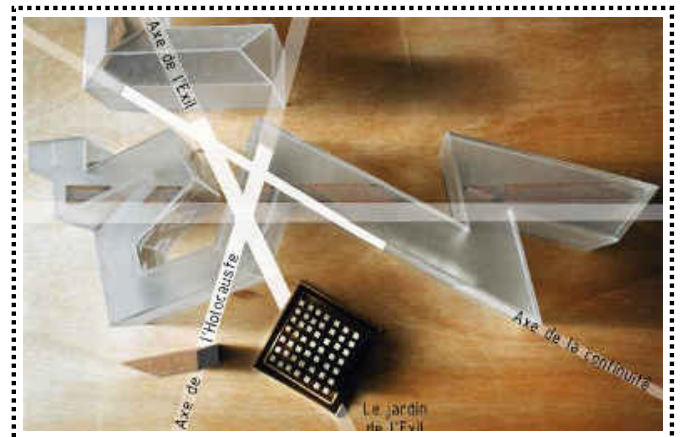

Fig. 37. The Jewish Museum Model showing the main Axis and Imaginary line.

Source:http://arq-contemporaneaagcbb.blogspot.com 
Daniel Libeskind researched the addresses of prominent Jewish and German citizens on a map of pre-war Berlin and joined the points to form an irrational and invisible matrix on which he based the language of form \& geometry, the lines of the walls are interrupted by oddly-placed windows of varying sizes, these windows serve several purposes, these windows suggest contact with the outside world, but they also prevent any view that is not fragmented, representing the fragmented history of Jews in Germany [14].

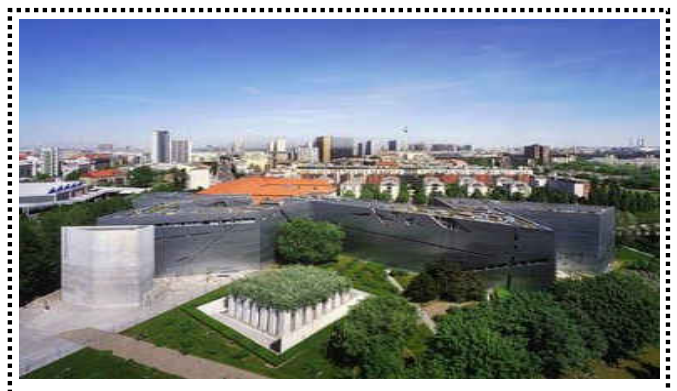

Fig. 38. The language of form, the geometry and shape of the building.

Source:http://arq-contemporaneaagcbb.blogspot.com

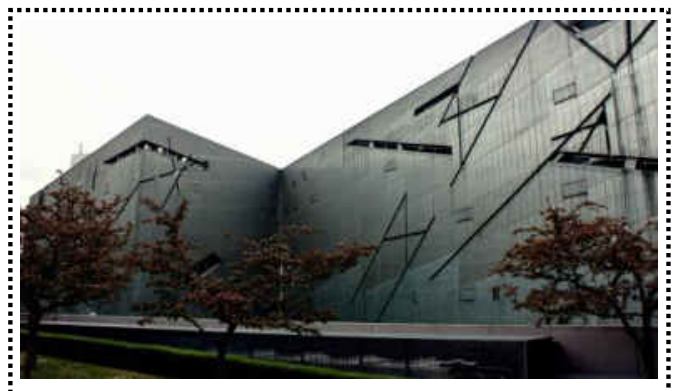

Fig. 39. The Oddly-placed windows, Jewish Museum perspective View.

Source:http://arq-contemporaneaagcbb.blogspot.com

This method is performative and addresses issues of represent ability by marking an absent presence, even for the visitor who might not pay attention to Libeskind's intended meanings behind the voids, cutting through the building spaces in which visitors physically move evokes something that is not there, each visitor who comes across these voids will re-mark this absence by negotiating the spaces around them, and yet the museum placards state that in the entrance to the museum, Libeskind provides no visible connection between past, present, and future, instead, he challenges visitors to find these themselves, the architect intends to create a mental activity of the visitors during their perception of the entire journey [4].
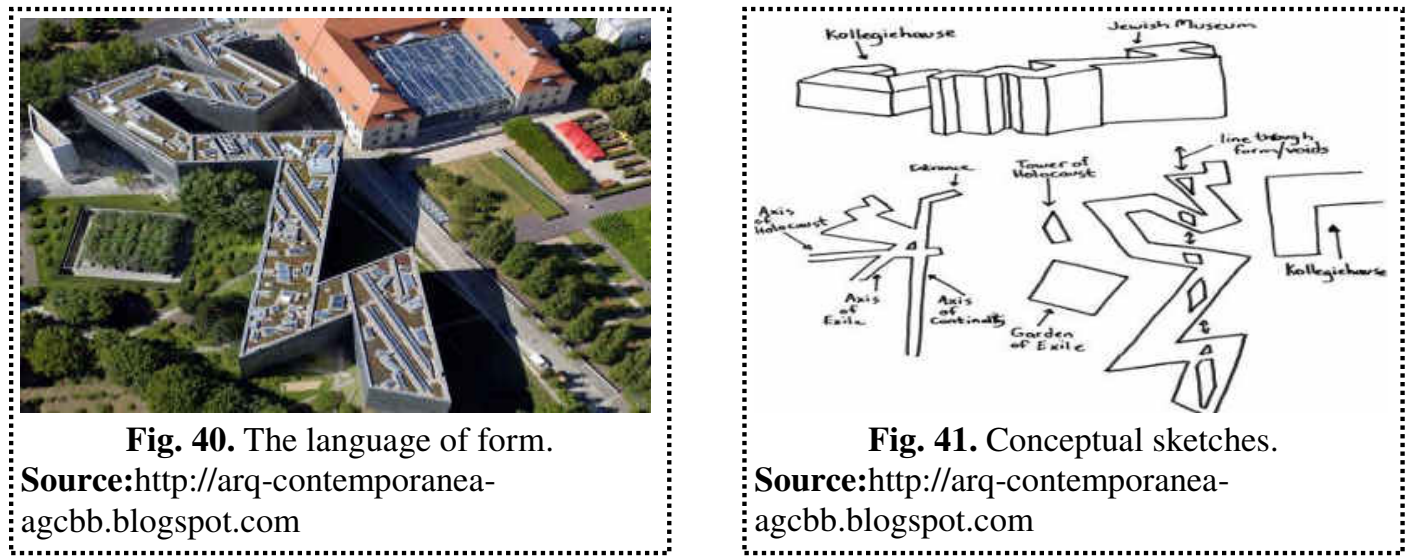

This is because the visitor's apprehension of the space from the moment they go down a flight of stairs to enter the first exhibit focuses on the Holocaust, which is eventually the main target of the commemoration, the sole entry point demands that visitors see this history as they walk through it, even if they just walk past it, their physical body has to interact with the space of representation, and they have to make a conscious decision to deny it intellectually, the museum's exhibits and building design continue to challenge visitors to take personal responsibility through 
conscious choices for the past, the present, and the future, once visitors descend the stairs, they are surrounded with white walls and black slate floors that slope upward, the information sign names it the Axis of Continuity and states: you are now underground, the point at which the visitor stands is a crossroads, the Axis of Exile and the Axis of the Holocaust cut across this Axis of Continuity and lead to the Garden of Exile and the Holocaust Tower [14].

The Axis of Exile leads to a glass door and the Axis of the Holocaust leads to a black door, this path of exile moves toward the Garden of Exile at the end of the hall, it widens, in contrast, the path to the Holocaust Tower narrows at the end, the tower is an empty, vertical void constructed with concrete that commemorates Holocaust victims, these are examples of how the building interacts performatively with the contents of the exhibit to reflect several metaphorical meanings that could physically and intellectually affect the visitor, even if they do not see this widening and narrowing, their body will sense it physically as an opening and closing of space, On the path of exile there is literally a "light at the end of a tunnel," but the use of a glass door also implies unseen obstacles, the garden is outside the building, to go outside, the visitor must open a large, uneven, and heavy door, the ground is slanted down as the visitor steps outside [14].
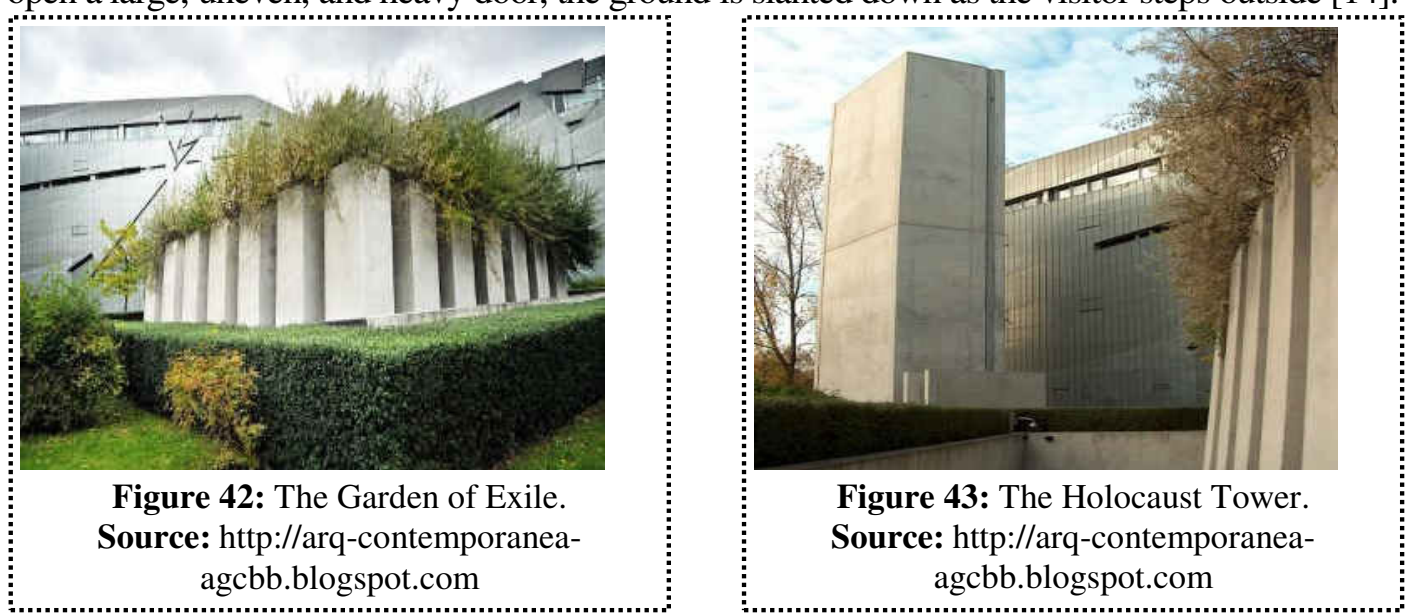

The garden is visible from the street, any citizen or visitor in Berlin can see and walk into this space as they pass by, the garden contains forty-nine pillars of concrete, each pillar is filled with earth in which willow and oaks grow, forty-eight columns contain the earth of Berlin, signifying the year 1948 and the formation of Israel, the forty-ninth column is filled with earth from Jerusalem and represents the Jewish presence in Berlin itself, the columns are vertical on a slanted ground, mimicking seasickness and making standing upright somewhat difficult, this is another important example of the ways in which the museum design provides meaning-making opportunities that can be apprehended intellectually but also must be apprehended physically and viscerally, visitors retrace their path along the Axis of Exile, high on the walls along this walkway on both sides are the names of cities to which exiled Jews escaped, citing places that provided refuge, and evoking these places by re-marking them [8].

The elements used as exhibition differs in the case of Jewish museums as it presents the objects in a different manner in order to create the perception through the visitors as he or she passes along, Among the exhibit methods used: first, fragmented chronology of the timeline of the events through the exhibits, second, the axial pathways leading to important features of the memorial site, the Garden of Exile \& the Holocaust Tower, third, graphic representations of the trauma such as: Simple banners hanging from the ceiling with dates, 
numbers, and names, Memorial book table, and fourth, photographs of (people, travelling documents, suitcases, watches, and jewellery) [8].

This is one way the museum brings attention to the construction of memory, through objects, stories, and facts that foreground memory, and the way memory situates the victim as complex and connected to history and place, visitors reflect on memory and history to make meaning with the space, the contents, and the objects dialogically in per formative memorialisation, once again, the building design provides several opportunities to evoke physical, intellectual, and emotional reactions from the visitor to metaphorically render absence present, both history and memory are recalled in such a museum, as well as the relationship of the past to the present, revealing the political and social nature of the memorial-making process and the true fragility of identity, history, and culture in the present, the Museum invites audiences to actively make meaning in its spaces through their reactive behaviour towards the halls, pathways and building features, the memorial's mission is attained by the perception of space rather than the observation of the exhibited objects in contrast with any other museum typology [8].

This brings back to light the fact that the exhibited objects in memorial muses is minimum diminishing the focus on the object display and rather focusing on the journey of the visitor and his or her perception of space.

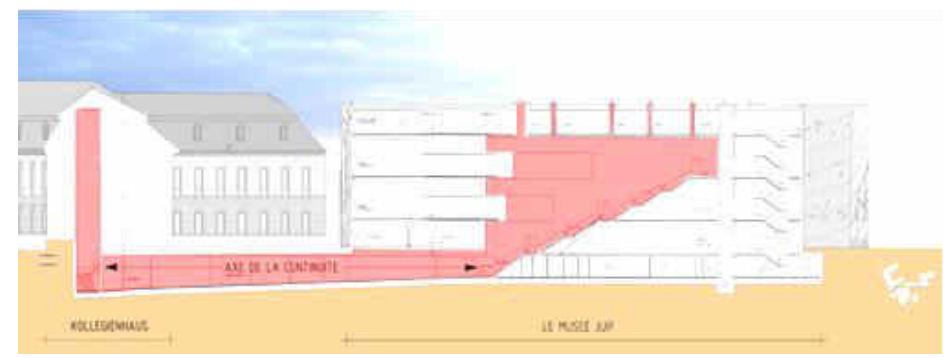

Fig. 44. Longitudinal section showing the axe of continuity.

Source: http://arq-contemporanea-agcbb.blogspot.com

\section{Conclusion}

Museums were initiated historically and considered worldwide based on common purpose, this purpose was mainly a result of the transfer of collections from the private to the public domain that has launched creation of the public Museum buildings, yet the nonstatic world has lead to the evolution of new configurations with respect to the museum mission, functionalities and symbolic form, the traditional mission of the museum had altered from being the house of specific museum functions, more particularly the functions of exhibition and display, preventive and remedial active conservation, study, management, and receiving visitors.

In conclusion:

- The museum world has evolved a great deal over the years, both in terms of its functions and through its materiality and the main elements upon which its work is built.

- Yet for the time being they are hardly facing the competition for exhibitions of real objects in traditional museums, yet it is not impossible that their development will affect the methods currently used by museums. 
- Museums today have turned to be a mass cultural tool; the mission of the museum is no longer restricted to the preservation and collection but also include of educational tasks.

- The primary factor as clarified was the technological revolution that had turned the museum exhibition concept of a place of collections into a large public space that adorns several activities and tasks, not to mention that the new trends of display methods and visualization modes are reducing the actual entity of the traditional exhibition halls.

- The previous analysis had showed also that the political unrest and its social implications are critical factors leading to the rise of new museum typologies, this justifies the hypothesis set, that these circumstances had a major impact on the museology itself.

- On the other hand, the analysis of the memorial museums history showed that this type of museums had became a social requirement denoted to the future of nations that are still attached to an event as the latter had a major impact on their entity of existence.

- Yet the case of deterioration of the museum mission of display arises many questions of the future of the museology generally and the memorial museums specifically especially that this typology is directly attached to the political and social unrest, will memorial museums become a permanent feature of the cultural and political landscape, or might they soon be exposed as passing trends?, What new typologies would the social behaviour and political implications invoke?, Where would the continuous relation between technology and mind kind be leading the place of muse?.

The discussion of the findings is enriched the talk in the domain of theories of Architecture and the relationship between community and museum, Then, the conclusion of the paper would be showing whether the actual mission of museums today is still taken into consideration within the new typologies as well as deriving the attained result after all the presented information to derive a general result proving the hypothesis stated, the historical target of museums had been subjected to many modifications due to the technological, political and social modifications that have altered the general mission of the museum as the house of collections, and the role of the museum is to increase the awareness of the society, architecture is a clear reflection of the society, so just like everything around us; it is subjected to dramatic changes, therefore it is not appropriate to design today in the manners, ideas, and believes of yesterday.

\section{REFERENCES}

[1] Alexander, P. (2008), "Museums In Motion: An Introduction To The History And Functions of Museums", AltaMira Press, United Kingdom.

[2] Dean, D. (1996), "Museum Exhibition: Theory and Practice", Routledge, New York.

[3] Desvallées, A., Mairesse, F. (Eds). (2010), "Key Concepts of Museology", Armand Colin, Paris.

[4] Dogan, F. and Nersessian, J. (2012), "Conceptual Diagrams In Creative Architectural Practice: The Case of Daniel Libeskind's Jewish Museum", Architectural Research Quarterly Journal, Volume 16, Issue 01, pp 15-27, Cambridge University Press, U.K.

[5] Greenaway, P. (2011), "The European Future Technologies Conference and Exhibition 2011", Elsevier B.V., Milano. 
[6] Groove, R. (1969), "Some Problems in Museum Education", in Museums and Education, ed. Eric Larrabee, Washington, DC: Smithsonian Institution.

[7] Gunay, B. (2012), "Museum Concept from Past to Present and Importance of Museums as Centers of Education", International Conference on New Horizon in Education (pp.12501258), Elsevier Ltd, Turkey.

[8] http://hosting.collectionsaustralia.net/omj/vol2/pdfs/stead.pdf (September 2014)

(Stead, N. (2000), "The Ruins of History: Allegories of Destruction in Daniel Libeskind's Jewish Museum Extension to the Berlin Museum", Open Museums Journal special edition: Unsavory Histories', ed. Anne Brake and Andrea Witcomb)

[9] http://en.wikipedia.org/wiki/Musaeum (September 2014)

[10] http://www.architectural-review.com/essays/typology-quarterly-museums/8640202.article (September 2014)

(Morata, A. (2012), "typology quarterly: museums", architectural review Journal)

[11] http://www.britannica.com/EBchecked/topic/398827/history-of-museums

(September 2014), (Geoffrey D. Lewis, Director of Museum Studies, University of Leicester, England, 1977-1989, President, International Council of Museums, 1983-1989)

[12] http://www.e-c-h-o.org/ca_archives_museums.php (September 2014)

[13] http://www.hparc.com/work/the-grand-egyptian-museum/ (September 2014)

[14] http://www.jmberlin.de/main/EN/04-About-The-Museum/01-Architecture/01-libeskindBuilding.php (September 2014)

(The Jewish Museum, Berlin, Official Web Page)

[15] Williams, P. (2007), "Memorial Museums: the global rush to commemorate atrocities", Berg, Oxford 


\section{المتاحف بين التقليد والحداثة: نموذج المتاحف التذكارية مثل متحف اليهود ببرلين كلدراسة حالة}

\section{ملخص البحث}

تعد الأهداف الرئيسية لهذه الورقـة البحثيـة هي: أولاً: إعـادة إكتشـاف بعض الحقائق الجديدة المتعلقة بتطور

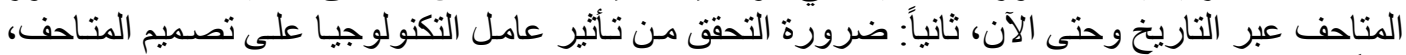

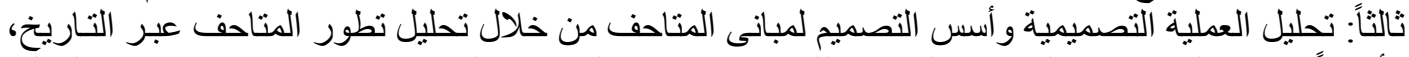

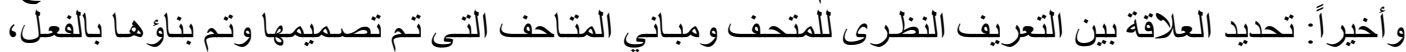

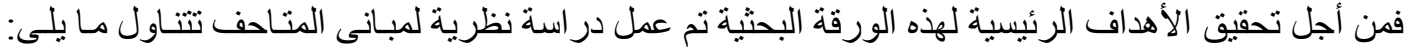

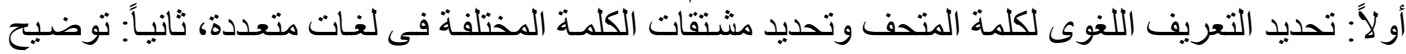

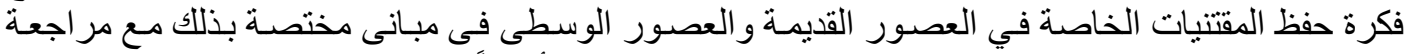

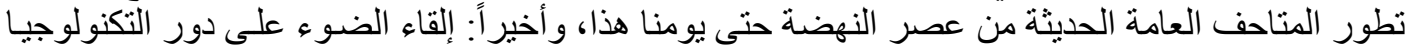

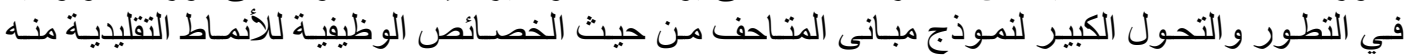

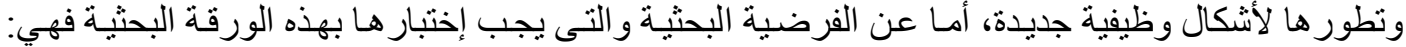

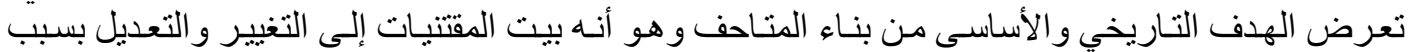

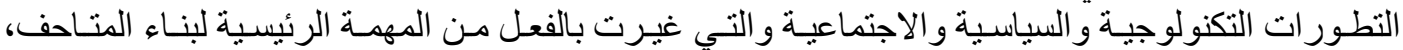

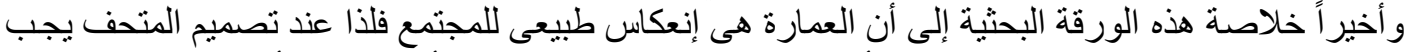

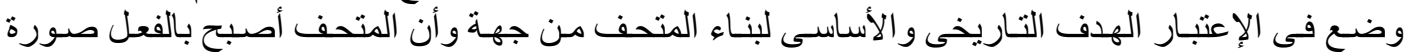

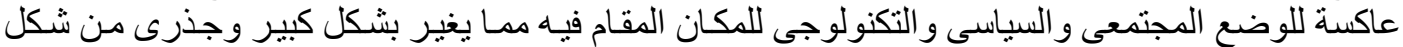

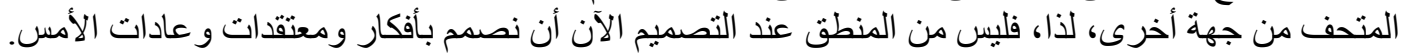
الكلمات المفتاحية: المتحف و المتحفية، الشكل و التشكيل، المتاحف التذكارية.
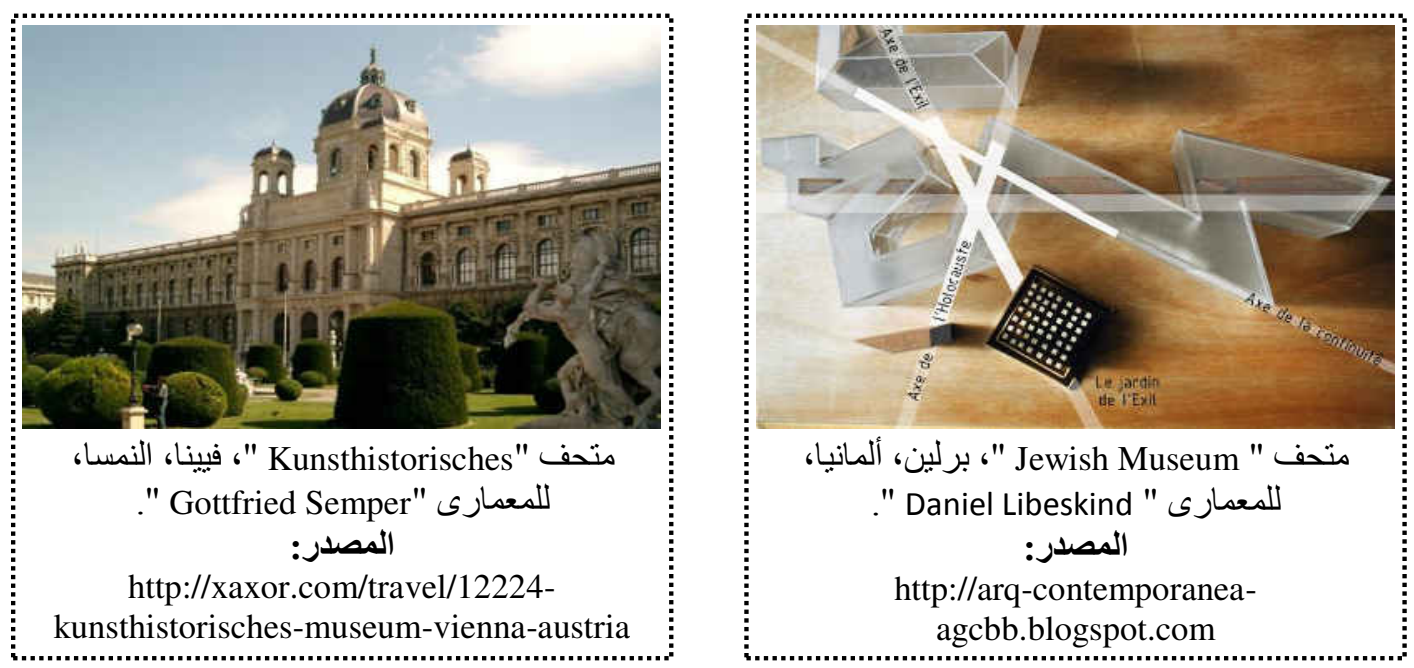